\title{
INERTISATION OF GALVANIC SLUDGE WITH CALCIUM OXIDE, ACTIVATED CARBON, AND PHOSPHORIC ACID
}

\author{
Višnja OREŠČANIN ${ }^{1}$, Ivanka LOVRENČIĆ MIKELIĆ ${ }^{2}$, Robert KOLLAR ${ }^{1}$, Nenad MIKULIĆ ${ }^{3}$, \\ and Gordana MEDUNIĆ ${ }^{4}$
}

Advanced Energy Ltd. ${ }^{1}$, Laboratory of Radioecology, R. Boskovic Institute ${ }^{2}$, EKO INVEST, Ltd., Zagreb, Croatia ${ }^{3}$, Institute of Mineralogy and Petrography, Faculty of Science, Zagreb, Croatia

Received in November 2011

CrossChecked in July 2012

Accepted in July 2012

\begin{abstract}
In this study we compared three methods for the treatment of electroplating sludge highly loaded with zinc and iron: (1) calcium oxide-based solidification/stabilisation; (2) conversion into inert material by adsorption of organic and inorganic pollutants onto activated carbon; and (3) conversion of mobile waste components into insoluble phosphates. All three methods proved highly efficient in the conversion of hazardous waste into inert material. Under optimum treatment conditions zinc concentration in the leachate of solidified waste was reduced by $99.7 \%$ compared to untreated sludge. Zinc retention efficiency in the waste treated with activated carbon and phosphoric acid was $99.9 \%$ and $98.7 \%$, respectively. The advantages of electroplating sludge treatment with activated carbon over the other two methods are high sorption capacity, insignificant $\mathrm{pH}$ and volume changes of the sludge, and simple use.
\end{abstract}

KEY WORDS: heavy metals, immobilization, leaching, solidification

Because of the high content of toxic heavy metals electroplating sludge is considered hazardous waste (1). On the other hand, this toxic waste could be reused as raw material for the extraction of zinc, chromium, and other valuable components to save natural resources. Various alkaline or acid based hydrometallurgical and electrochemical processes have been used for this purpose (1-6), but their major disadvantage is that they yield large amounts of sludge that needs to be neutralised (rendered inert) before landfilling. If metal extraction is not economically justified, such material has to be converted to nonhazardous waste by solidification/stabilisation and can be reused in cement industry (7-11). Although there are more than a hundred electroplating facilities in Croatia, most of them zinc plating, there either recovery or inertisation of electroplating sludge have been regulated (12). As this sludge contains high concentrations of zinc in the leachate, and the $\mathrm{pH}$ value is usually below 3 , it poses a considerable threat to the environment and people, which has been confirmed by toxicological tests on various bio-systems for the concentration of zinc that are even lower than $2 \mathrm{mg}$ $\mathrm{L}^{-1}(13-19)$.

Oreščanin et al. (20) developed the first method to treat electroplating sludge in Croatia that is based on solidification/stabilisation of sludge with $\mathrm{CaO}$ in order to convert hazardous waste into inert material. Our preliminary results have confirmed that the method is highly efficient for the specific purpose. In this study we wanted to analyse two new methods for sludge inertisation based on the application of powdered activated carbon and phosphoric acid and to compare them with the $\mathrm{CaO}$ method in terms of efficiency in 
binding heavy metals, sludge production, simplicity of implementation, and cost.

\section{MATERIALS AND METHODS}

\section{Sampling and sample handling}

For inertisation experiments we took samples of electroplating sludge from Tvik electroplating facility (Knin, Croatia). Sampling and sample handling has already been described in detail in our previous article (20).

\section{Solidification/stabilization procedure}

The electroplating sludge was solidified/stabilised with calcium oxide (Lika lime factory, Ličko Lešće, Croatia) as described in our previous work (20) and after air-drying subjected to the leaching test according to DIN38414-S4 procedure.

\section{Sludge inertisation using activated carbon}

A composite sample of sludge was mixed with $1 \%, 2 \%, 3 \%, 4 \%, 5 \%$, and $6 \%$ of powdered activated carbon (p.a. Kemika, Zagreb) in relation to the dry weight of the sludge. The mixture $(5.9 \mathrm{~g})$ was homogenised for $10 \mathrm{~min}$, air dried at room temperature $\left(22^{\circ} \mathrm{C}\right)$, and subjected to the DIN38414-S4 leaching test.

\section{Sludge inertisation using phosphoric acid}

A composite sample of sludge was mixed with $1 \%, 2 \%, 3 \%, 4 \%$, and $5 \%$ of phosphoric acid
(Kemika, Zagreb) in relation to the dry weight of the sludge. The mixture $(5.9 \mathrm{~g})$ was homogenised for 10 min, air dried at room temperature $\left(22^{\circ} \mathrm{C}\right)$, and subjected to the DIN38414-S4 leaching test.

\section{Analysis of parameters in solid and liquid samples}

Dry matter and organic matter content were measured overnight by loss on ignition at $105^{\circ} \mathrm{C}$ and $375^{\circ} \mathrm{C}$, respectively. Elemental concentrations in solid samples were determined using the energy dispersive X-ray fluorescence method (EDXRF) (21). DIN 38414-S4 leachates of original and inertised samples were prepared as described in our earlier studies (20, 22). Instrumental settings as well as quality control have been described in detail in our earlier research $(21,22)$.

\section{RESULTS AND DISCUSSION}

\section{Basic physico-chemical characteristic of the electroplating sludge}

Table 1 shows that the prevailing elements of toxicological significance in untreated electroplating sludge were iron, zinc, chromium, nickel, and lead. Sludge also contained a significant amount of organic matter $(9.4 \%$ to $29.4 \%)$. High chelating potential of these organic constituents was the most probable reason for low leaching of chromium, lead, and copper from the sludge. Lead concentration in the DIN38414-S4 leachate was below the detection limit $(0.001 \mathrm{mg}$ $\left.\mathrm{L}^{-1}\right)$ in all tested samples while mean chromium and copper values were $0.096 \mathrm{mg} \mathrm{L}^{-1}$ and $0.053 \mathrm{mg} \mathrm{L}^{-1}$ of leachate, respectively (Table 2 ). These findings have

Table 1 Element content in bulk samples of untreated electroplating sludge

\begin{tabular}{lcccccc}
\hline $\begin{array}{l}\text { Measured } \\
\text { parameter }\end{array}$ & Mean & SD & RSD & Median & Minimum & Maximum \\
\cline { 2 - 7 } $\mathrm{Ca} / \mathrm{mg} \mathrm{kg}^{-1}$ & 73000 & 39900 & 0.55 & 65000 & 13000 & 152000 \\
\hline $\mathrm{Ti} / \mathrm{mg} \mathrm{kg}^{-1}$ & 451.7 & 53.61 & 0.12 & 463 & 365 & 557 \\
\hline $\mathrm{Cr} / \mathrm{mg} \mathrm{kg}^{-1}$ & 207.2 & 197.42 & 0.95 & 131 & 21 & 759 \\
\hline $\mathrm{Mn} / \mathrm{mg} \mathrm{kg}^{-1}$ & 439.4 & 110.23 & 0.25 & 440.5 & 207 & 598 \\
\hline $\mathrm{Fe} / \mathrm{mg} \mathrm{kg}^{-1}$ & 136000 & 47900 & 0.35 & 151600 & 38400 & 191400 \\
\hline $\mathrm{Ni} / \mathrm{mg} \mathrm{kg}^{-1}$ & 278.3 & 67.99 & 0.24 & 273 & 185 & 418 \\
\hline $\mathrm{Cu} / \mathrm{mg} \mathrm{kg}^{-1}$ & 133.3 & 72 & 0.54 & 122.5 & 16 & 317 \\
\hline $\mathrm{Zn} / \mathrm{mg} \mathrm{kg}^{-1}$ & 33400 & 12600 & 0.38 & 31800 & 10900 & 58200 \\
\hline $\mathrm{Pb} / \mathrm{mg} \mathrm{kg}^{-1}$ & 109.9 & 62.25 & 0.57 & 114.5 & 11 & 235 \\
\hline $\mathrm{Dry} \mathrm{Matter} / \mathrm{mg} \mathrm{kg}^{-1}$ & 253000 & 83200 & 0.33 & 243000 & 125000 & 455000 \\
\hline $\mathrm{LOI} 375{ }^{\circ} \mathrm{C} / \mathrm{mg} \mathrm{kg}^{-1}$ & 197000 & 52900 & 0.27 & 183000 & 94000 & 294000
\end{tabular}

$S D$-standard deviation; $R S D$-relative standard deviation 
confirmed our previous research (22-24) showing high susceptibility of these three elements to organic lygands. The DIN38414-S4 leachate composition shows that this sludge was not suitable for landfilling with inert waste since mean zinc and nickel were 10 and 1.5 times higher than the upper permissible limit, and the maximum zinc and nickel values were 27 and 2.5 times higher than the upper permissible limit, respectively (25).

Zinc concentration in the leachate of untreated sludge ranged from $0.3 \mathrm{mg} \mathrm{L}^{-1}$ to up to $107 \mathrm{mg} \mathrm{L}^{-1}$ with the mean value of $40.3 \mathrm{mg} \mathrm{L}^{-1}$. In our earlier study (13), we found that zinc concentrations higher than $25 \mathrm{mg} \mathrm{L}^{-1}$ were cytotoxic to TA98 and TA100 Salmonella typhimurium strains while $100 \mathrm{mg} \mathrm{L}^{-1}$ of zinc significantly increased the frequency of micronucleated cells and reduced mitotic activity of human peripheral blood lymphocytes. In another study (14) the survival rates for HeLa and HEp2 human cells were only $2.3 \%$ and $0.3 \%$, respectively, after treatment with electroplating wastewater having zinc concentration of $562 \mathrm{mg} \mathrm{L}^{-1}$, while $99.5 \%$ diluted sample significantly increased all comet assay parameters compared to negative control.

Durgo et al. reported (15) less than $15 \%$ survival of the TA98 and TA100 Salmonella typhimurium strains after the treatment with electroplating wastewater having zinc concentration of $505 \mathrm{mg} \mathrm{L}^{-1}$ (15) while Horvat et al. (17) found that $51 \mathrm{mg} \mathrm{L}^{-1}$ and $126 \mathrm{mg} \mathrm{L}^{-1}$ of zinc have a significant toxic effect on Lemna minor.

In another study (19), zinc concentration of $86 \mathrm{mg} \mathrm{L}^{-1}$ significantly increased all comet assay parameters after exposure of peripheral blood lymphocytes to the leachate of electric arc furnace dust. All these findings suggest that untreated electroplating sludge could endanger human health and plant bio-systems if released directly into the environment (leaching by precipitation).

\section{Sludge inertisation with $\mathrm{CaO}$}

Figure 1a shows to which extent calcium oxide treatment lowered heavy metal concentrations in the
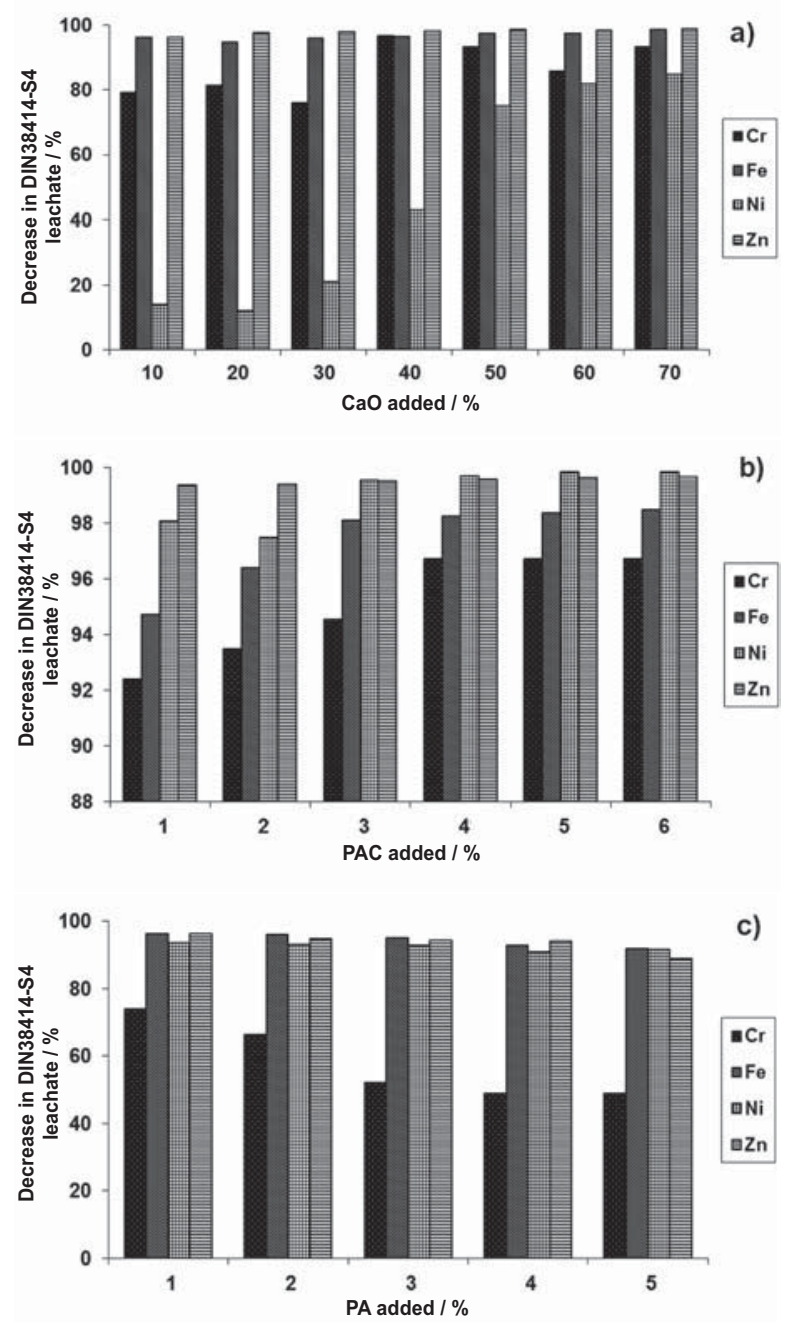

Figure 1 Decrease in heavy metal concentrations in the DIN38414-S4 leachate of treated waste compared to untreated electroplating sludge for different dosages of: a) calcium oxide; b) powdered activated carbon (PAC); c) phosphoric acid (PA)

Table 2 Heavy metal concentrations in the leachate DIN38414-S4 of untreated electroplating sludge and maximum allowed concentrations

\begin{tabular}{|c|c|c|c|c|c|c|}
\hline \multirow{2}{*}{ Statistical parameter } & \multicolumn{6}{|c|}{ Measured parameter } \\
\hline & $\mathrm{Cr} / \mathrm{mg} \mathrm{L}^{-1}$ & $\mathrm{Fe} / \mathrm{mg} \mathrm{L}^{-1}$ & $\mathrm{Ni} / \mathrm{mg} \mathrm{L}^{-1}$ & $\mathrm{Cu} / \mathrm{mg} \mathrm{L}^{-1}$ & $\mathrm{Zn} / \mathrm{mg} \mathrm{L}^{-1}$ & pH \\
\hline Mean & 0.096 & 15.725 & 0.634 & 0.053 & 40.320 & 4.34 \\
\hline SD & 0.047 & 9.970 & 0.306 & 0.194 & 27.997 & 0.80 \\
\hline RSD & 0.486 & 0.634 & 0.483 & 3.691 & 0.694 & 0.19 \\
\hline Median & 0.090 & 14.307 & 0.634 & 0.003 & 34.746 & 4.06 \\
\hline Minimum & 0.006 & 0.345 & 0.082 & 0.001 & 0.349 & 3.42 \\
\hline Maximum & 0.183 & 34.085 & 1.052 & 0.829 & 107.475 & 5.90 \\
\hline MAV (25) & 0.5 & - & 0.4 & 2 & 4 & - \\
\hline
\end{tabular}

$S D$-standard deviation; $R S D$-relative standard deviation 
DIN38414-S4 leachate of electroplating sludge compared to untreated sludge. Treatment with the lowest dosage of $\mathrm{CaO}(10 \%)$ already lowered all elemental concentrations below the lowest limit for the landfilling (25) and these concentrations dropped linearly with increasing $\mathrm{CaO}$ concentration. The exception is nickel, which dropped below the acceptable limit only at $40 \% \mathrm{CaO}$.

Although, lime-based solidification is a method of choice for solidification of municipal solid waste (2628 ), the use of this method for solidification of waste oil, oily wastes, and other waste by-products with high organic content has scarcely been investigated and only a few studies investigated its use in the solidification of inorganic sludges. Silva et al. (3) showed high efficiency of a two-phase sludge solidification method that included clay and lime in the first step and Portland cement, sand, and water in the second. Other authors (29) found that hydrated lime and black rice husk ash in the presence of either $\mathrm{Na}_{2} \mathrm{SiO}_{3}$ or $\mathrm{Na}_{2} \mathrm{CO}_{3}$ activators significantly reduced heavy metals leaching, especially of zinc, which was immobilised in the form of calcium zincate and calcium zinc silicate.

Extremely low leaching of arsenic was observed after solidification of inorganic sludge with cement, fly ash, and $\mathrm{Ca}(\mathrm{OH})_{2}$ in the weight ratio $3: 1: 0.5: 0.5$ (30) confirming excellent binding capacity of this mixture.

Hydrated lime was also used for the immobilisation of heavy metals in highly contaminated soil having a similar chemical composition as electroplating sludge. $\mathrm{At} \mathrm{Ca}(\mathrm{OH})_{2}$ and soil ratio of 0.0375 the concentration of heavy metals $\mathrm{Cd}, \mathrm{Co}, \mathrm{Ni}, \mathrm{Pb}$ and $\mathrm{Zn}$ in the leachate were decreased below minimum detection limit (31).

The advantage of $\mathrm{CaO}$-based solidification is that solidification and chemical stabilisation of waste sludge occur simultaneously due to exothermic hydration of calcium oxide. The porosity, hydrophobicity, fire resistance, and good thermal and acoustic properties of the obtained solid matter make it suitable for use in sectors such as civil engineering. Moreover, $\mathrm{CaO}$ is readily available and less expensive than the other two additives. Solidification is less expensive in terms of equipment and trained operators and can be used easily in large companies and small family businesses alike.

The major disadvantage is that for $\mathrm{CaO}$ to be effective with heavy metals retention it has to be added in large quantities (at least $40 \%$ ), which generates more waste than the other two methods.

\section{Sludge inertisation with powdered activated carbon}

The regulatory requirements for landfilling of inert waste (25) were met for all elements with only $1 \%$ of PAC (Table 4). Zinc concentration in the leachate dropped 159 times compared to untreated sludge. $\mathrm{Cr}$, $\mathrm{Fe}, \mathrm{Ni}$ and $\mathrm{Zn}$ concentration dropped $92.4 \%, 94.7 \%$, $98.1 \%$, and $99.4 \%$, respectively (Figure $1 b$ ). Heavy metal concentrations dropped linearly with further addition of PAC.

Although, activated carbon, either in granular or powdered form, is commonly used for the adsorption of organic (32-34) and inorganic matter (35-37) in wastewaters, we have not found a single article on immobilization of heavy metals with this adsorbent in industrial sludges.

PAC turned out to be more effective in reducing heavy metal leaching than the other two methods (Figure 2) due to high adsorption capacity. PAC only

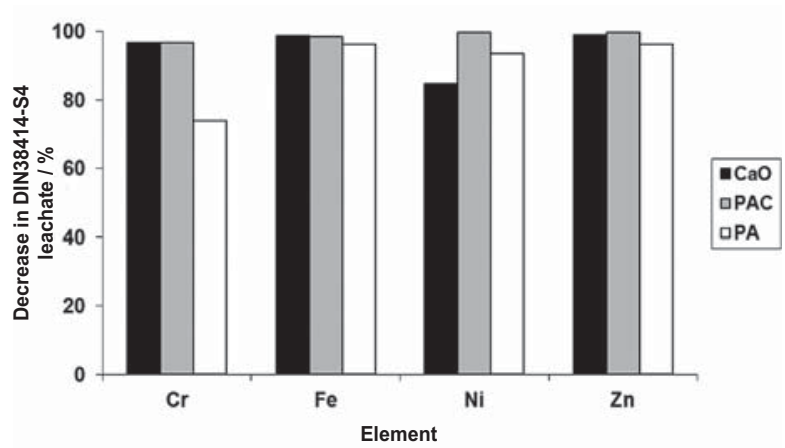

Figure 2 Comparison of the best performance results for three treatment method of electroplating sludge. PACpowdered activated carbon; PA-phosphoric acid

slightly changes $\mathrm{pH}$ and the volume of the treated sludge in relation to untreated sludge. Treatment process is simple, does not require expensive equipment and trained personnel, and is easily applied by large companies and small family businesses alike. The adsorbent does not require special precautions for handling and storage. The major disadvantages over $\mathrm{CaO}$ are that $\mathrm{PAC}$ is less available and more expensive and that treated sludge needs additional drying.

\section{Sludge inertisation with phosphoric acid}

The addition of $1 \%$ of phosphoric acid showed the best results in the retention of all elements in waste sludge. $\mathrm{Cr}, \mathrm{Fe}, \mathrm{Ni}$, and $\mathrm{Zn}$ concentration dropped in the leachate by $73.9 \%, 96.2 \%, 93.7 \%$, and $96.3 \%$, respectively (Figure 1c) and all elements met regulatory requirements for landfilling of inert waste 
Table 3 Elemental concentration in DIN38414-S4 leachate of galvanic sludge beforelafter treatment with different dosages of $\mathrm{CaO}$ and upper permissible limit for inert waste (MAV)

\begin{tabular}{|c|c|c|c|c|c|c|c|c|c|}
\hline \multirow[t]{2}{*}{ Element } & \multirow{2}{*}{$\begin{array}{c}\text { Concentration before } \\
\text { treatment / } \mathrm{mg} \mathrm{L}^{-1}\end{array}$} & \multirow{2}{*}{ MAV (25) } & \multicolumn{7}{|c|}{ Concentration after $\mathrm{CaO}$ added / $\mathrm{mg} \mathrm{L}^{-1}$} \\
\hline & & & $10 \%$ & $20 \%$ & $30 \%$ & $40 \%$ & $50 \%$ & $60 \%$ & $70 \%$ \\
\hline $\mathrm{Cr}$ & 0.092 & 0.5 & 0.019 & 0.017 & 0.022 & 0.003 & 0.006 & 0.013 & 0.006 \\
\hline $\mathrm{Fe}$ & 13.113 & & 0.477 & 0.673 & 0.504 & 0.439 & 0.333 & 0.317 & 0.175 \\
\hline $\mathrm{Ni}$ & 0.681 & 0.4 & 0.586 & 0.599 & 0.537 & 0.389 & 0.169 & 0.122 & 0.103 \\
\hline $\mathrm{Zn}$ & 37.900 & 4 & 1.380 & 0.787 & 0.781 & 0.679 & 0.488 & 0.532 & 0.348 \\
\hline
\end{tabular}

Table 4 Elemental concentration in DIN38414-S4 leachate of galvanic sludge beforelafter treatment with different dosages of powdered activated carbon (PAC) and upper permissible limit for inert waste (MAV)

\begin{tabular}{|c|c|c|c|c|c|c|c|c|}
\hline \multirow[t]{2}{*}{ Element } & \multirow{2}{*}{$\begin{array}{c}\text { Concentration before } \\
\text { treatment } / \mathrm{mg} \mathrm{L}^{-1}\end{array}$} & \multirow{2}{*}{$\begin{array}{l}\text { MAV } \\
(25)\end{array}$} & \multicolumn{6}{|c|}{ Concentrationa after PAC added / $\mathrm{mg} \mathrm{L}^{-1}$} \\
\hline & & & $1 \%$ & $2 \%$ & $3 \%$ & $4 \%$ & $5 \%$ & $6 \%$ \\
\hline $\mathrm{Cr}$ & 0.092 & 0.5 & 0.007 & 0.006 & 0.005 & 0.003 & 0.003 & 0.003 \\
\hline $\mathrm{Fe}$ & 13.113 & & 0.691 & 0.473 & 0.247 & 0.229 & 0.213 & 0.198 \\
\hline $\mathrm{Ni}$ & 0.681 & 0.4 & 0.013 & 0.017 & 0.003 & 0.002 & 0.001 & 0.001 \\
\hline $\mathrm{Zn}$ & 37.900 & 4 & 0.239 & 0.222 & 0.174 & 0.153 & 0.139 & 0.127 \\
\hline
\end{tabular}

Table 5 Elemental concentration in DIN38414-S4 leachate of galvanic sludge before/after treatment with different dosages of phosphoric acid (PA) and upper permissible limit for inert waste (MAV)

\begin{tabular}{|c|c|c|c|c|c|c|c|}
\hline \multirow{2}{*}{ Element } & \multirow{2}{*}{$\begin{array}{l}\text { Concentration before } \\
\text { treatment / } \mathrm{mg} \mathrm{L}^{-1}\end{array}$} & \multirow{2}{*}{ MAV (25) } & \multicolumn{5}{|c|}{ Concentration after $\mathbf{P A}$ added / $\mathrm{mg} \mathrm{L}^{-1}$} \\
\hline & & & $1 \%$ & $2 \%$ & $3 \%$ & $4 \%$ & $5 \%$ \\
\hline $\mathrm{Cr}$ & 0.092 & 0.5 & 0.024 & 0.031 & 0.044 & 0.047 & 0.047 \\
\hline $\mathrm{Fe}$ & 13.113 & & 0.495 & 0.528 & 0.653 & 0.941 & 1.059 \\
\hline $\mathrm{Ni}$ & 0.681 & 0.4 & 0.043 & 0.047 & 0.049 & 0.061 & 0.057 \\
\hline $\mathrm{Zn}$ & 37.900 & 4 & 1.393 & 1.964 & 2.101 & 2.201 & 4.201 \\
\hline
\end{tabular}

(Table 5). Further addition of phosphoric acid caused linear increase in leachate heavy metals concentrations probably trough the formation of soluble complexes.

Over the last few years a new effective method has been introduced for waste inertisation with phosphoric acid. This method has been developed by Solvay for inertisation of sediments in ports and shipyards with high heavy metal and organic matter loads and has been patented under the name of Novosol ${ }^{\circledR}$. It can transform highly mobile heavy metals into hardly soluble metal phosphates and destroy organic matter with heat $(38,39)$. Yang and Mosby (40) used phosphoric acid for successful in situ immobilisation of lead in contaminated soil while Zupančič et al. (41) used the same method to immobilise nickel and zinc in sewage sludge and reduced significantly leaching of either metal.

High retention rate of heavy metals (Table 5) and other components in treated sludge, slight changes in $\mathrm{pH}$, and a small amount needed are the major advantages of the phosphoric acid-based method. Its major disadvantage is that it involves special handling and storage, higher operational costs, lower efficiency in heavy metal binding, treated sludge needs additional drying.

\section{CONCLUSION}

All three treatment methods can efficiently convert hazardous waste into inert material and reduce its adverse effects on the environment and human health (13-19). Inertization with powdered activated carbon showed best performance (Figure 2). Its other advantages are insignificant changes in $\mathrm{pH}$ and volume of treated sludge, small amount needed, and simplicity of the application. On the other hand, $\mathrm{CaO}$-based solidification is the least expensive method and the obtained solidificate is suitable for reuse. 


\section{REFERENCES}

1. Jandová J, Štefanová T, Niemczyková R. Recovery of Cuconcentrates from waste galvanic copper sludges. Hydrometallurgy 2000;57:77-84.

2. Vegliò F, Quaresima R, Fornari P, Ubaldini S. Recovery of valuable metals from electronic and galvanic industrial wastes by leaching and electrowinning. Waste Manag 2003;23:245-52

3. Silva JE, Soares D, Paiva AP, Labrincha JA, Castro F. Leaching behaviour of a galvanic sludge in sulphuric acid and ammoniacal media. J Hazard Mater 2005;121:195202.

4. Miškufova A, Havlik T, Laubertova M, Ukašík M. Hydrometallurgical route for copper, zinc and chromium recovery from galvanic sludge. Acta Metallurgica Slovaca 2006;12:293-302.

5. Rossini G, Bernardes AM. Galvanic sludge metals recovery by pyrometallurgical and hydrometallurgical treatment. J Hazard Mater 2006;131:210-6.

6. Chen D, Yu Y-Z, Zhu H-J, Liu Z-Z, Xu Y-F, Liu Q, Qian G-R. Ferrite process of electroplating sludge and enrichment of copper by hydrothermal reaction. Sep Pur Technol 2008;62:297-303.

7. Espinosa DCR, Tenório JAS. Laboratory study of galvanic sludge's influence on the clinkerization process. Resour Conserv Recycl 2000;31:71-82.

8. Ract PG, Espinosa DCR, Tenório JAS. Determination of $\mathrm{Cu}$ and $\mathrm{Ni}$ incorporation ratios in Portland cement clinker. Waste Manage 2003;23:281-5.

9. Magalhães JM, Silva JE, Castro FP, Labrincha JA. Role of the mixing conditions and composition of galvanic sludges on the inertization process in clay-based ceramics. J Hazard Mater 2004;106B:169-76.

10. Magalhães JM, Silva JE, Castro FP, Labrincha JA. Effect of experimental variables on the inertization of galvanic sludges in clay-based ceramics. J Hazard Mater 2004;106B:13947.

11. Magalhães JM, Silva JE, Castro FP, Labrincha JA. Kinetic study of the immobilization of galvanic sludge in clay-based matrix. J Hazard Mater 2005;121:69-78.

12. Oreščanin V, Mikelic L, Lulić S, Nad K, Mikulić N, Rubčić M, Pavlović G. Purification of electroplating waste waters utilizing waste by-product ferrous sulfate and wood fly ash. J Environ Sci Health Part A Tox Hazard Subst Environ Eng 2004;39:2437-46.

13. Oreščanin V, Kopjar N, Durgo K, Garaj Vrhovac V, Franekić Colić J, Ramić S, Nad K, Valković V. Toxicological characterization of the new water cleaning product and its waste by-product. J Environ Sci Health Part A Tox Hazard Subst Environ Eng 2004;39:1281-94.

14. Oreščanin V, Kopjar N, Durgo K, Elez L, Findri-Guštek S, Franekić Colić J. Citotoxicity status of electroplating wastewater prior/after neutralization/purification with alkaline solid residue of electric arc furnace dust. J Environ Sci Health Part A Tox Hazard Subst Environ Eng 2009;44:2738.

15. Durgo K, Horvat T, Oreščanin V, Mikelić L, Franekić Colić J, Lulić S. Cytotoxicity and mutagenicity study of waste and purified water samples from electroplating industries prepared by use of ferrous sulfate and wood fly ash. J Environ
Sci Health Part A Tox Hazard Subst Environ Eng 2005;40:94957.

16. Durgo K, Oreščanin V, Lulić S, Kopjar N, Želježić D, Franekić Colić J. The assessment of genotoxic effects of wastewater from the fertiliser factory. J Appl Toxicol 2009;29:42-51.

17. Horvat $T$, Vidaković-Cifrek Z, Oreščanin V, Tkalec M, Pevalek-Kozlina B. Toxicity assessment of heavy metal mixtures by Lemna minor L. Sci Total Environ 2007;384:22938.

18. Gajski G, Oreščanin V, Garaj Vrhovac V. Cytogenotoxicity of sewage sludge leachate before and after calcium oxide based solidification in human lymphocytes. Ecotoxicol Environ Saf 2011;74:1408-15.

19. Garaj Vrhovac V, Oreščanin V, Ruk D, Gajski G. In vitro assessment of genotoxic effects of electric arc furnace dust on human lymphocytes using the alkaline comet assay. J Environ Sci Health Part A Tox Hazard Subst Environ Eng 2009;44:279-87.

20. Oreščanin V, Mikulić N, Lovrenčić Mikelić I, Posedi M, Kampić Š, Medunić G. The bulk composition and leaching properties of electroplating sludge prior/following the solidification/stabilization by calcium oxide. J Environ Sci Health Part A Tox Hazard Subst Environ Eng 2009;44:12828 .

21. Oreščanin V, Lovrenčić Mikelić I, Mikelić L, Lulić S. Applicability of MiniPal 4 compact EDXRF spectrometer for soil and sediment analysis. X-ray Spect 2008;37:50811.

22. Elez L, Oreščanin V, Sofilić T, Mikulić N, Ruk D. Application of alkaline solid residue of electric arc furnace dust for neutralization/purification of electroplating wastewaters. J Environ Sci Health Part A Tox Hazard Subst Environ Eng 2008;43:1417-23.

23. Oreščanin V, Lulić $\mathrm{S}$, Pavlović G, Mikelić L. Granulometric and chemical composition of the Sava river sediments upstream and downstream of the Krsko nuclear power plant. Environ Geol 2004;46:605-14.

24. Oreščanin V, Tibljaš D, Valković, V. A study of coagulant production from red mud and its use for heavy metals removal. J Trace Microprobe Techn 2002;20:233-45.

25. Pravilnik o načinima i uvjetima odlaganja otpada, kategorijama i uvjetima rada za odlagališta otpada [Ordinance on the methods and conditions for the landfill of waste, categories and operational requirements for waste landfills for landfilling of inert waste, in Croatian]. Narodne novine $117 / 2007$.

26. Lim S, Jeon W, Lee J, Lee K, Kim N. Engineering properties of water/wastewater-treatment sludge modified by hydrated lime, fly ash and loess. Water Res 2002;36:4177-84.

27. Rhew RD, Barlaz MA. Effect of lime-stabilized sludge as landfill cover on refuse decomposition. J Environ Eng 1995:121:499-506.

28. Spence RD, Mattus AJ. Laboratory stabilizations/solidification of tank sludges: MVST/BVEST. J Environ Manage 2004;70:189-202.

29. Piyapanuwat R, Asavapisit S. Performance of lime-BHA solidified plating sludge in the presence of $\mathrm{Na}_{2} \mathrm{SiO}_{3}$ and $\mathrm{Na}_{2} \mathrm{CO}_{3}$. J Environ Manage 2011;92:2222-8.

30. Singh TS, Pant KK. Solidification/stabilization of arsenic containing solid wastes using portland cement, fly ash and polymeric materials. J Hazard Mater 2006:131:29-36. 
31. Hale B, Evans L, Lambert R. Effects of cement or lime on $\mathrm{Cd}, \mathrm{Co}, \mathrm{Cu}, \mathrm{Ni}, \mathrm{Pb}, \mathrm{Sb}$ and $\mathrm{Zn}$ mobility in field-contaminated and aged soils. J Hazard Mater 2012:199-200:119-27.

32. Harrelkas F, Azizi A, Yaacoubi A, Benhammou A, Pons MN. Treatment of textile dye effluents using coagulationflocculation coupled with membrane processes or adsorption on powdered activated carbon. Desalination 2009;235:3309.

33. Hai FI, Yamamoto K, Nakajima F, Fukushi K. Removal of structurally different dyes in submerged membrane fungi reactor-Biosorption/PAC-adsorption, membrane retention and biodegradation. J Membrane Sci 2008;325:395-403.

34. Nicolet L, Rott U. Recirculation of powdered activated carbon for the adsorption of dyes in municipal wastewater treatment plants. Water Sci Technol 1999;40:191-8.

35. Dialynas E, Diamadopoulos E. Integration of immersed membrane ultrafiltration with coagulation and activated carbon adsorption for advanced treatment of municipal wastewater. Desalination 2008;230:113-27.

36. Oztürk N, Bektaş TE. Nitrate removal from aqueous solution by adsorption onto various materials. J Hazard Mater 2004;112:155-62.
37. Patnukao P, Kongsuwan A, Pavasant P. Batch studies of adsorption of copper and lead on activated carbon from Eucalyptus camaldulensis Dehn bark. J Environ Sci 2008;20:1028-34.

38. Ndiba P, Axe L, Boonfueng T. Heavy metal immobilization through phosphate and thermal treatment of dredged sediments. Environ Sci Technol 2008;42:920-6.

39. Ramaroson J, Dirion J-L, Nzihou A, Depelsenaire G. Characterization and kinetics of surface area reduction during the calcination of dredged sediments. Powder Technol 2009;190:59-64.

40. Yang J, Mosby D. Field assessment of treatment efficacy by three methods of phosphoric acid application in leadcontaminated urban soil. Sci Total Environ 2006;66:13642.

41. Zupančič M, Bukovec N, Milačič R, Ščančar, J. Comparison of various phosphate stabilisation agents for the immobilisation of $\mathrm{Ni}$ and $\mathrm{Zn}$ in sewage sludge. Water Air Soil Pollut 2004;156:57-69. 


\section{Sažetak}

\section{INERTIZACIJA GALVANSKOG MULJA S POMOĆU KALCIJEVA OKSIDA, AKTIVNOG UGLJENA I FOSFORNE KISELINE}

U radu su prikazani i uspoređeni rezultati triju metoda obrade galvanskog mulja visoko opterećenog cinkom i željezom: (1) solidifikacija/stabilizacija otpada primjenom kalcijeva oksida; (2) inertizacija otpada adsorpcijom organskog i anorganskog opterećenja na aktivni ugljen; (3) prevođenje mobilnih komponenata otpada u teško topljive fosfate. Sve tri metode pokazale su se efikasnima u prevođenju opasnog otpada u inertno stanje. Kod optimalnih uvjeta koncentracija cinka u eluatu solidificiranog otpada snizila se za 99,7 \% u odnosu prema neobrađenom otpadu. Efikasnost retencije cinka u otpadu inertiziranom aktivnim ugljenom iznosila je 99,9\%, a fosfornom kiselinom 98,7 \%. Prednost inertizacije aktivnim ugljenom u odnosu prema ostalim dvjema metodama očituje se visokim sorpcijskim kapacitetom, neznatnim promjenama $\mathrm{pH}$-vrijednosti i volumena tretiranog otpada, kao i jednostavnošću primjene.

KLJUČNE RIJEČI: CaO, izluživanje, praškasti aktivni ugljen, teški metali

\section{CORRESPONDING AUTHOR:}

Višnja Oreščanin

Advanced Energy Ltd., V. Prekrata 43, Zagreb, Croatia

E-mail:vorescan@gmail.com 